\title{
Genetic Parameters and Correlation between Tomato Late Blight Field Resistance and Fruit Quality
}

\author{
Carlos Nick ${ }^{1}$, Jorge Gonzalez Aguilera ${ }^{2}$, Bruno Soares Laurindoㄹ, Victor de Souza Almeida ${ }^{1}$, \\ Renata Dias de Freitas' ${ }^{1}$ Cosme Damião Cruz ${ }^{3}$, Derly José Henriques da Silva1 \\ ${ }^{1}$ Departamento de Fitotecnia, Universidade Federal de Viçosa, Viçosa, Brazil \\ ${ }^{2}$ Embrapa Trigo, Passo Fundo, Brazil \\ ${ }^{3}$ Departamento de Biologia Geral, Universidade Federal de Viçosa, Viçosa, Brazil \\ Email: carlosnickg@gmail.com
}

Received 25 May 2014; revised 28 June 2014; accepted 9 July 2014

Copyright (C) 2014 by authors and Scientific Research Publishing Inc.

This work is licensed under the Creative Commons Attribution International License (CC BY).

http://creativecommons.org/licenses/by/4.0/

(c) (i) Open Access

\begin{abstract}
The objective of this study was to estimate genetic parameters and quantify the correlations between late blight (LB) resistance and fruit quality traits in 220 families $F_{2: 3}$, under tropical field conditions. The families were arranged in randomized blocks in field trials, with six resistant inbred lines used as control, in plots of five plants. It evaluated the severity in the middle of the epidemy, final severity, area under the curve of progress of late blight, $\mathrm{pH}$, total soluble solids, titratable acidity and flavor. There is genetic variability for epidemiological variables and total soluble solids. Heritabilities, obtained by parent-offspring regression, were high and indicated the possibility of satisfactory genetics gains and success in the introgression of resistance alleles. The correlations were negative, of high to intermediate magnitude, among the variables area under the curve of progress of late blight, total soluble solids and total titratable acidity.
\end{abstract}

\section{Keywords}

Pre-Breeding, Alleles Introgression, Genetic Resources, Tomato Wild Species

\section{Introduction}

Late blight (LB) caused by the oomycete Phytophthora infestans (Mont.) de Bary, is the most destructive disease in the cultivated tomato, Solanum lycopersicum L. [1]. LB can attack tomato aerial parts, causing necrosis of leaves and stems, fruit losses and eventually plant death. Control methods of this disease include cultural 
practices and fungicides spray. However, the chemical control (i.e. fungicide spray) is dependent on the cost of the applications and may have its efficacy reduced if the weather conditions are favorable to the pathogen [2].

Cultivars with genetic resistance are a desirable alternative in reducing the environmental and economic fungicide spray coast [3]. The resistance alleles both qualitative and quantitative resistance were in wild species, such as Solanum pimpinellifolium L. [4] and Solanum habrochaites S. Knapp \& D.M. Spooner [3] [5]-[7]. Wild germplasms alleles for introgression in elite cultivars are a great challenge for plant breeders. The introduction of exotic alleles in elite cultivars may lead to increase in the expression of the undesirable agronomic traits, due to the genetic linkage drag [8].

This phenomenon occurs when chromosome segments containing alleles of interest are linked to loci that contain deleterious alleles from the horticultural traits [3], limiting thus the action of the breeder regarding the simultaneous selection of traits related to fruit quality. This makes it necessary to perform additional work for the introduction of these alleles, thus causing more time for obtaining a resistant cultivar.

In order to elucidate the association between LB resistance traits and fruit quality, the objective of this study was to estimate genetic statistical parameters and correlations in $220 \mathrm{~F}_{2: 3}$ Solanum habrochaites f. glabratum progenies.

\section{Material and Methods}

\subsection{Plant Genetic Resources}

The susceptible cultivar "Santa Clara", S. lycopersicum L., was used as female genitor in crossing with BGH 6902 accession, S. habrochaites f. glabratum, LB resistant. The female genitor belongs to the "Santa Cruz" brazilian fresh market tomato group, it has bi or triloculars oblong fruits, consumed in natura and fruits weight 130 $\mathrm{g}$ in average. Male genitor is a wild specie kept on the Banco de Germoplasma de Hortaliças da Universidade Federal de Viçosa (BGH/UFV - www.bgh.ufv.br) and produce small greenish fruits with unpleasant taste and odor. Part of the $F_{1}$ plants was self-pollinated for the obtantion of $F_{2}$ generation, which originated $220 F_{2: 3}$.

\subsection{Experimental Conditions and Field Trials}

The experiments were carried out at the experimental area of the Universidade Federal de Viçosa (UFV), in Viçosa, MG State, Brazil, located in the latitude $20^{\circ} 45^{\prime} 14$ "S, longitude $42^{\circ} 52^{\prime} 53^{\prime \prime} \mathrm{W}$ and $648.74 \mathrm{~m}$ high.

In 2010 it was evaluated $220 \mathrm{~F}_{2: 3}$ families for LB resistance, divided in two trials, both in randomized blocks with two repetitions and six common controls in each trial: the lines 127f, 64b, 73d e 133a [5] and genitors. The sowing of the seeds was done in polystyrene trays with 128 cells, which were kept under greenhouse conditions until the seedlings reach six true leaves. In this stage, the seedlings were transplanted to the field spaced 1 and $0.6 \mathrm{~m}$ between rows and plants, respectively.

The growing methods followed the instructions of [9]. The plots were composed by five plants and the evaluations done on the three central plants. In the first trial, seedlings of 119 families were transplanted in the field on the 14 of June of 2010. The transplanting of the second trial was done on the 10 of August of 2010, totalizing 101 families.

\subsection{P. infestans Isolates e Inoculation}

$P$. infestans isolates pathogenic to tomato, from the towns of Cajuri, Coimbra, Teixeiras and Viçosa, located at Zona da Mata Mineira, Minas Gerais state, were used for the inoculums preparation, according metology [6].

Infected leaflets were collected and kept in plastic trays previously disinfected in $70 \%$ alcohol, lined with paper towels moistened in distilled water and kept at $18^{\circ} \mathrm{C}$ for $24 \mathrm{~h}$ for incubation. After the incubation period, foliar lesions with mycelium and sporangia were removed and placed in flasks with distilled water. Subsequently, the mixture was stirred in an agitator to form a sporangia suspension. The concentration of the suspensions was adjusted by hemacytometer to $5 \times 10^{3}$ sporangia per $\mathrm{mL}$. Then, equal volumes from four locals were mixed. The sporangia suspension was placed in refrigerator for $1 \mathrm{~h}$, at a temperature of about $4^{\circ} \mathrm{C}$, to induce zoospores release.

Inoculation of seedlings occurred 50 days after transplanting in the field. The inoculation was done at the dusk with backpack sprayer, applying approximately $10 \mathrm{~mL}$ of the suspension per plant. The period from the inoculums preparation to inoculation was less than $2 \mathrm{~h}$, avoiding unfeasibility of zoospores. The plants were 
watered at dusk by sprinkling for $2 \mathrm{~h}$ three times a week until the end of the experiment.

\subsection{Fruit Quality Analyses}

The fruit quality traits, total acidity $(\mathrm{pH})$; total soluble solids ( $\left.{ }^{\circ} \mathrm{Brix}\right)$, measured with a portable refractometer, total titrable acidity (\% citric acid) and flavor, obtained by the ratio of total soluble solids and total titrable acidity, were measured using samples of five fruits picked on the second and third cluster. These analyses were performed according to the analytical standard proposed by the [10].

\subsection{Disease Quantification}

The disease was quantified by the percentage of the disease severity (DS) in intervals of three days, for 15 days [6]. In the evaluations, two evaluators were trained using the software Severity Pro (1.0), in order to increase the visual accuracy in the field and notes were assigned to the leaves of each plant, according to the diagrammatic scale proposed by [11].

The DS were subsequently used to estimate the area under the disease progress curve (AUDPC), and the other epidemiological traits: severity on the middle of the epidemy $\left(\mathrm{Y}_{50}\right)$ and final severity $\left(\mathrm{Y}_{\mathrm{Max}}\right)$. It was considered, as the duration of the epidemy, the time between the first and the last evaluation. The phenotypic values of each family were obtained by the average of the grades attributed to the leaves of the three central plants of each plot.

\subsection{Statistical and Genetic Analysis}

The analysis of variance were conducted using the joint analysis for the group of experiments, which were analyzed together with the common (controls) and non common (families) treatments, so that the comparison between then were done indistinctly of the trial where they were evaluated. This procedure was used in function of the great number of families, and it was used the first scheme, according to the methodology proposed by [12]. For this analysis scheme, the authors recommended to observe the variables which the interaction controls vs. trials is significant, as for the comparison between two random families the data should be corrected by the environmental effect, calculated from the information from the controls. For this correction to be possible, the controls may not have a differential behavior due to the environmental variations and should measure only the environmental quality [13].

The statistical and genetic parameters estimated were: the experimental coefficient of variation, genetic coefficient of variation, ratio between the genetic variation coefficient and environmental variation, the component of genetic variance, heritability in a broad sense in level of the averages of $F_{2: 3}$ families, heritability parentoffspring and the phenotypic, genotypic and environmental correlation between the epidemiological variables and fruit quality attributes.

The parent-offspring heritability for the phenotypic variables, $\mathrm{Y}_{50}, \mathrm{Y}_{\mathrm{MAX}}$ and area under the curve of progress of late blight was obtained according to the methodology proposed by Smith and Kinman (1965), described by [14]. The ANOVA and the estimation of the statistical and genetic parameters were performed using the software Genes [15].

\section{Results and Discussion}

The joint analysis of variance showed not to be significant the interaction between controls vs. trials for the traits evaluated. Coefficients of experimental variation of high values were estimated for $\mathrm{Y}_{50}, \mathrm{Y}_{\mathrm{MAX}}$ and AUDPC (Table 1).

Because it is an average value between two trials, high estimates can be due to climatic differences between the periods of evaluation of severity in each trial. However, the values are similar to the ones found by [5]. High coefficient of variation for epidemiological traits can be due to the differences between the progress rate of the disease in the families and the difficulty in obtaining homogeneity in the grades attributed to the same treatment [16]. The average values of the coefficients of variation of the quality traits were intermediate and agree to the values obtained by [5], which evaluated these same traits in strains derived from the cross between S. lycopersicum and S. habrochaites f. glabratum. Significant effects among the $\mathrm{F}_{2: 3}$ families were observed in level of $1 \%$ of probability, by the $\mathrm{F}$ test, for the traits $\left(\mathrm{Y}_{50}\right),\left(\mathrm{Y}_{\mathrm{Max}}\right)$ and (AUDPC). For the trait total soluble solids ( ${ }^{\circ}$ Brix), there was significance at $5 \%$ of probability. These results show the presence of genetic variability for these traits 
in the population under study, condition that allows the selection of genotypes with superior agronomic performance quality traits.

The estimates of the parameters, coefficient of genetic variation, ratio between coefficient of genetic variation/experimental and heritability, are of great value for the breeding, once they are also used on the quantification of the available genetic variability. The coefficient of genetic variation, $\mathrm{CV}_{\mathrm{g}}$, gives an idea about the proportionality of the gain in relation to the average in case of selection, and the ration $\mathrm{CV}_{\mathrm{g}} / \mathrm{CV}_{\mathrm{e}}>1$ indicates favorable situation to selection [17]. The values of the coefficients of genetic variation were intermediate and low (Table 2) and showed that higher gains would be obtained when the selection were practiced under the epidemic traits. However, values of the ration $\mathrm{CV}_{\mathrm{g}} / \mathrm{CV}_{\mathrm{e}}$ lower than one in all traits indicate unfavorable condition of the practice of selection.

The heritability shows how much of the phenotypic variation is due to the genetic effects. So, if the values of heritability are high, there is a high correlation between the phenotypic and genotypic value, so that the meas-

Table 1. Summary of the joint analysis of variance of 220 families $F_{2: 3}$ derived from the cross between Solanum lycopersicum and Solanum habrochaites f. glabratum evaluated for epidemiological and fruit quality, together with six commons controls in both trials.

\begin{tabular}{|c|c|c|c|c|c|c|c|c|}
\hline \multirow{2}{*}{ SV } & \multirow{2}{*}{ DF } & \multicolumn{7}{|c|}{ Mean squares } \\
\hline & & $\mathbf{Y}_{50}$ & $\mathbf{Y}_{\text {MAX }}$ & AUDPC & $\mathbf{p H}$ & ${ }^{\circ}$ Brix & TTA & Flavor \\
\hline Blocks/trials & 2 & 5216.49 & 15484.60 & 951751.97 & 0.63 & 3.99 & 0.0049 & 161.51 \\
\hline Trials & 1 & 2829.61 & 16998.59 & 17108.59 & 0.43 & 0.56 & 0.0117 & 510.86 \\
\hline Control & 5 & 447.17 & 1078.40 & 73612.10 & 0.06 & 0.80 & 0.0050 & 76.52 \\
\hline Control $\times$ trials & 5 & $87.26^{\text {ns }}$ & $220.77^{\mathrm{ns}}$ & $8958.10^{\mathrm{ns}}$ & $0.03^{\mathrm{ns}}$ & $0.43^{\mathrm{ns}}$ & $0.0007^{\mathrm{ns}}$ & $11.46^{\mathrm{ns}}$ \\
\hline Families & 218 & $165.77^{*}$ & $374.77^{*}$ & $23057.94^{*}$ & $0.20^{\mathrm{ns}}$ & $1.04^{* *}$ & $0.0026^{\text {ns }}$ & $100.19^{\text {ns }}$ \\
\hline (Cont. vs. fam.)/trial. & 2 & 549.41 & 684.96 & 130542.89 & 0.11 & 2.35 & 0.0049 & 85.32 \\
\hline Residual & 230 & 90.52 & 216.89 & 10811.67 & 0.17 & 0.83 & 0.0022 & 93.41 \\
\hline Total & 463 & & & & & & & \\
\hline General average & & 18.68 & 40.10 & 280.31 & 4.19 & 3.94 & 0.15 & 27.175 \\
\hline Families average & & 18.92 & 40.34 & 284.46 & 4.19 & 3.94 & 0.15 & 27.29 \\
\hline Control's average & & 14.29 & 35.81 & 204.28 & 4.28 & 4.06 & 0.17 & 24.86 \\
\hline CV\% & & 50.90 & 36.71 & 37.09 & 10.00 & 23.09 & 30.72 & 35.56 \\
\hline
\end{tabular}

${ }^{*}$ and ${ }^{* *}$ significant by the $\mathrm{F}$ test $(\mathrm{P}<0.01$ e 0.05$)$; $\mathrm{Y}_{50}=$ severity in the middle of the epidemy; $\mathrm{Y}_{\mathrm{MAX}}=$ final severity; AUDPC = area under the curve of progress of late blight; $\mathrm{pH}=$ potential of hydrogen; ${ }^{\circ} \mathrm{Brix}=$ total soluble solids; TTA = total tritable acidity and flavor.

Table 2. Estimates of average genotypic variance $\left(V_{g}\right)$, broad-sense heritability $\left(h_{a}^{2}\right)$, genetic coefficient of variation $\left(C V_{g}\right)$, experimental coefficient of variation $\left(\mathrm{CV}_{\mathrm{e}}\right)$, ratio between experimental and environmental variation $\left(\mathrm{CV}_{\mathrm{g}} / \mathrm{CV}_{\mathrm{e}}\right)$, for epidemiological traits related to the resistance to late blight and fruit quality in progenies of tomato derived from the cross between Solanum lycopersicum and Solanum habrochaites f. glabratum.

\begin{tabular}{cccccccc}
\hline Parameter & $\mathbf{Y}_{\mathbf{5 0}}$ & $\mathbf{Y}_{\text {Max }}$ & AUDPC & $\mathbf{p H}$ & ${ }^{\circ}$ Brix & TTA & Flavor \\
\hline $\mathrm{V}_{\mathrm{g}}$ & 37.62 & 78.93 & 6123.13 & 0.01 & 0.11 & 0.01 & 3.38 \\
$\mathrm{~h}_{\mathrm{a}}^{2}$ & 45.39 & 42.12 & 53.11 & 14.04 & 20.77 & 12.97 & 6.76 \\
$\mathrm{CV}_{\mathrm{g}}$ & 32.40 & 22.02 & 27.50 & 2.86 & 8.37 & 8.44 & 6.74 \\
$\mathrm{CV}_{\mathrm{e}}$ & 50.90 & 36.71 & 37.09 & 10.00 & 23.09 & 30.72 & 35.56 \\
$\mathrm{CV}_{\mathrm{g}} / \mathrm{CV}_{\mathrm{e}}$ & 0.63 & 0.59 & 0.74 & 0.28 & 0.36 & 0.27 & 0.18 \\
\hline
\end{tabular}

$\mathrm{Y}_{50}=$ severity in the middle of the epidemy; $\mathrm{Y}_{\mathrm{Max}}=$ final severity; AUDPC = area under the curve of progress of late blight; $\mathrm{pH}=$ potential of hydrogen; ${ }^{\circ}$ Brix = total soluble solids; e TTA = total tritable acidity; flavor: ratio between total soluble solids and total tritable acidity. 
ured differences in the individuals translate the true genetic differences and guarantee thus the success of the selection strategy adopted [14].

The values of heritability of the fruit quality traits were low (Table 2) and indicated that low increments in average values of these traits would be obtained in following generations in case of the selection of the families were practiced. There was no correlation between the estimated values and the values reported in the literature. For example, [18], reported values of heritability of $43 \%$ for $\mathrm{pH}$ and higher than $80 \%$ for total soluble solids, total tritable acidity and flavor. However, caution is needed when analyzing the values of heritability because their estimate is specific to the experimental conditions which the genotypes were evaluated [19].

Regarding to the epidemiological traits, the estimates of the broad-sense heritability were lower than $50 \%$, except for AUDPC, which estimate was 53.11\% (Table 2). This value was similar to the value obtained by [5] and indicated that most of the phenotypic variation observed in the trait is due to a genetic cause. The results are satisfactory, once the heritability is a genetic parameter that expresses the reliability in the phenotypic value in predicting the genotypic value [14].

The heritability estimated by parent-offspring were satisfactory: $62.72 \%$ for $\mathrm{Y}_{50}, 56.61 \%$ for $\mathrm{Y}_{\mathrm{MAX}}$ and $71.20 \%$ AUDPC (Table 3). These values of heritability indicated that the LB resistance conferred by Solanum habrochaites f. glabratum (BGH 6902) can be easily introgressed. In similar studies, [4] reported high values of heritability for the LB resistance in Solanum pimpinellifolium progenies, estimated by parent-offspring regression, and stressed that this methodology of estimate provides a estimate close to the restrict heritability, thus preferable when phenotypic variations observed between the genitor $\left(F_{2}\right)$ and progenies $\left(F_{2: 3}\right)$ are due to the differences in the conditions which the traits were measured, as in evaluations in distinct season for example. According to these considerations, the estimates presented can be considered trustful and more accurate than those estimated in the broad-sense. Such results are encouraging, once satisfactory genetic progress can be achieved regarding the LB resistance by the use of BGH 6902.

Besides the analysis of population parameters, the correlations between the phenotypic traits assist in the understanding of the genic effect of the trait of interest [19]. When the traits are analyzed in progenies derived from the interspecific crosses, knowing the magnitude and direction of the correlations between the progenies is an important step, as normally during the process of introgression of an allele of economic interest from a wild specie to an elite-cultivar, another alleles that are undesirable are also transferred. That happens, generally, due to the drag linkage. In tomato, the introgression of alleles of resistance to late blight from wild species results in depreciation of attributes related to fruit quality, which is undesirable from the market point of view.

For the combination between epidemiological traits, the estimates of genetic correlation was of magnitude higher than 0.9 (Table 4) and the environmental correlations were positive, indicating a tendency that the expression of these traits are influenced equally by the environment. It is noteworthy that, for these traits, the phenotypic correlations were lower than the genotypic, condition checked when at least one of the traits involved presents high heritability [19] and genetic factors have higher influence in the determination of the correlation compared to the environmental factors [20]. The [16] affirmed that the AUDPC of late blight is more precise and accurate as the other traits $\left(\mathrm{Y}_{50}\right.$ e $\left.\mathrm{Y}_{\mathrm{Max}}\right)$ in representing the level of resistance of the progeny, and it should be preferred because it combines information related to the epidemy, including inoculum, environment and susceptibility of the host.

AUDPC was considered the trait that best represented the response of the progeny in relation to the resistance to the pathogen. Because of the genotypic variance, statistically null, estimated for the fruit quality attributes, it was not estimated the genetic correlation between these traits and the area under the curve of progress of late blight. The association between these traits was realized by phenotypic correlations (Table 5).

Table 3. Estimates of parent-offspring heritability, Smith and Kinman (1965), of epidemiological traits related to the resistance to late blight in progenies of tomato derived from the cross between Solanum lycopersicum and Solanum habrochaites f. glabratum.

\begin{tabular}{|c|c|c|c|c|c|}
\hline Parameters & $F_{2}$ average & $F_{2: 3}$ average & $\operatorname{Cov}\left(F_{2} ; F_{2: 3}\right)$ & Correlation & $\mathbf{h}^{2}$ \\
\hline $\mathrm{Y}_{50}$ & 3.30 & 18.05 & 9.86 & 0.23 & 62.72 \\
\hline $\mathrm{Y}_{\text {Max }}$ & 39.89 & 52.53 & 125.12 & 0.27 & 56.51 \\
\hline AUDPC & 161.17 & 279.49 & 5418.96 & 0.48 & 71.20 \\
\hline
\end{tabular}

$\mathrm{Y}_{50}=$ severity in the middle of the epidemy; $\mathrm{Y}_{\mathrm{Max}}=$ final severity; and AUDPC = area under the curve of progress of late blight. 
Table 4. Phenotypic (P), genotypic (G) and environmental (E) correlations between epidemiological traits related to the resistance to late blight in progenies of tomato derived from the cross between Solanum lycopersicum e Solanum habrochaites f. glabratum.

\begin{tabular}{cccc} 
Traits & Correlations & Y $_{\text {MAX }}$ & AUDPC \\
\hline & P & 0.63 & 0.87 \\
Y $_{50}$ & G & 0.97 & 0.99 \\
& E & 0.40 & 0.76 \\
$Y_{\text {Max }}$ & P & - & 0.76 \\
& G & - & 0.92 \\
\hline
\end{tabular}

$\mathrm{Y}_{50}=$ severity in the middle of the epidemy; $\mathrm{Y}_{\mathrm{Max}}=$ final severity; and AUDPC = area under the curve of progress of late blight.

Table 5. Correlations between the area under the curve of progress of late blight and fruit quality attributes in progenies of tomato derived from cross between Solanum lycopersicum e Solanum habrochaites f. glabratum.

\begin{tabular}{ccccc}
\hline Traits & pH & Brix & TTA & Flavor \\
\hline AUDPC & $0.27^{* *}$ & $-0.41^{* *}$ & $-0.31^{* *}$ & 0.02 \\
pH & - & 0.08 & -0.03 & $0.34^{* *}$ \\
BRIX & - & - & $0.48^{* *}$ & $0.44^{* *}$ \\
TTA & - & - & - & $-0.47^{* *}$ \\
\hline
\end{tabular}

** and ${ }^{*}$ significant at $1 \%$ and $5 \%$ of probability by the t test; AUDPC = area under the curve of progress of late blight; $\mathrm{pH}=$ potencial of hydrogen; ${ }^{\circ}$ Brix = total soluble solids; TTA = total tritable acidity; and flavor = ratio between total soluble solids and total tritable acidity.

The correlations between AUDPC, ${ }^{\circ}$ Brix and ATT were significant, negative and of intermediate magnitude, indicating that alleles of resistance can contribute favorably for the organoleptic qualities of the fruits, as the ratio between the content of total soluble solids and total tritable acidity determines the flavor. The results found ratified the reports by [21].

\section{Conclusions}

These authors concluded that the alleles of S. habrochaites were responsible for an increment of $15 \%$ in the content of soluble solids, emphasizing that wild germplasms are potentially donators of alleles of agronomic interest for elite-cultivars. The content of soluble solids ( ${ }^{\circ}$ Brix) positively correlated with total tritable acidity, agreed in magnitude and direction to the estimates obtained by [22], of 0.49 . The tritable acidity itself has negative association in relation to the flavor.

Through the results, it appears that there is genetic variability for all traits in the population under study. However, low values of heritability of the fruit quality traits were found. The estimates of heritability by parentspring regression were high and indicated the possibility of satisfactory gains, in addition to greater ease in the introgression of alleles of resistance. The correlations between the traits AUDPC, ${ }^{\circ}$ Brix and TTA were negative and of intermediate magnitude, indicating that alleles of resistance can favorably contribute to the flavor of the fruits.

It found genetic variability for all traits. The quality attributes of fruits have low heritability, while the heritability parent-offsspring epidemiological variables were of great magnitude indicating the possibility of satisfactory earnings.

\section{Acknowledgements}

To Fundação de Amparo à Pesquisa do Estado de Minas Gerais, for financial support; to Coordenação de Aperfeiçoamento de Pessoal de Nível Superior and Conselho Nacional de Desenvolvimento Tecnológico e Cientifico, for scholarship granted. To Universidade Federal de Viçosa. 


\section{References}

[1] Fry, W. (2008) Phytophthora infestans: The Plant (and R Gene) Destroyer. Molecular Plant Pathology, 9, 385-340. http://dx.doi.org/10.1111/j.1364-3703.2007.00465.x

[2] Foolad, M.R., Merk, H.L. and Ashrafi, H. (2008) Genetics, Genomics and Breeding of Late Blight and Early Blight Resistance in Tomato. Critical Reviews in Plant Sciences, 27, 75-107. http://dx.doi.org/10.1080/07352680802147353

[3] Brouwer, D.J. and Clair, D.S. (2004) Fine Mapping of Three Quantitative Trait Loci for Late Blight Resistance in Tomato Using near Isogenic Lines (NILs) and Sub-NILs. Theoretical and Applied Genetics, 108, 628-638. http://dx.doi.org/10.1007/s00122-003-1469-8

[4] Merk, H.L. and Foolad, M.R. (2011) Parent-Offspring Correlation Estimate of Heritability for Late Blight Resistance Conferred by an Accession of the Tomato Wild Species Solanum pimpinellifolium. Plant Breeding, 131, 1-8.

[5] Fiorini, C.V., Silva, D.D., Mizubuti, E.S., Barros, J.D.S., Silva, L.D., Milagres, C. and Zaparoli, M.R. (2010) Caracterização de linhagens de tomateiro originadas de cruzamento interespecífico quanto à resistência à requeima. Horticultura Brasileira, 28, 197-202. http://dx.doi.org/10.1590/S0102-05362010000200010

[6] Abreu, F.B., Silva, D.J.H., Cruz, C.D. and Mizubuti, E.S.G. (2008) Inheritance of Resistance to Phytophthora infestans (Peronosporales, Pythiaceae) in a New Source of Resistance in Tomato (Solanum sp. (formerly Lycopersicon sp.), Solanales, Solanaceae). Genetics and Molecular Biology, 31, 493-497. http://dx.doi.org/10.1590/S1415-47572008000300016

[7] Brouwer, D.J., Jones, E.S. and Clair, D.A.S. (2004) QTL Analysis of Quantitative Resistance to Phytophthora infestans (Late Blight) in Tomato and Comparisons with Potato. Genome, 47, 475-492. http://dx.doi.org/10.1139/g04-001

[8] Monforte, A.J. and Tanksley, S.D. (2000) Fine Mapping of a Quantitative Trait Locus (QTL) from Lycopersicum hirsutum Chromosome 1 Affecting Fruit Characteristics and Agronomic Traits: Breaking Linkage among QTLs Affecting Different Traits and Dissection of Heterosis for Yield. Theoretical Applied Genetics, 100, 471-479. http://dx.doi.org/10.1007/s001220050061

[9] Guimarães, M.A., Calimam, F.R.B., Silva, D.J.H., Marim, B.G. and Souza, J.B. (2011) Tratos Culturais do Tomateiro. In: Silva, D.J.H. and Vale, F.X.R., Eds., Tomate: Tecnologia de produção. Editora Suprema, Visconde do Rio Branco, 85-99.

[10] Instituto Adolfo Lutz (2008) Métodos fisíco-químico para análise de alimentos. Instituto Adolfo Lutz, São Paulo.

[11] Corrêa, F.M., Bueno Filho, J.S.S. and Carmo, M.G.F. (2009) Comparison of Three Diagrammatic Keys for the Quantification of Late Blight in Tomato Leaves. Plant Pathology, 58, 1128-1133. http://dx.doi.org/10.1111/j.1365-3059.2009.02140.x

[12] Cruz, C.D. and Carneiro, P.C.S. (2003) Modelos biométricos aplicados ao melhoramento genético. Editora UFV, Viçosa.

[13] Marim, B.G., Silva, D.J.H., Carneiro, P.C.S., Miranda, G.V., Mattedi, A.P. and Caliman, F.R.B. (2009) Variabilidade genética e importância relativa de caracteres em acessos de germoplasma de tomateiro. Pesquisa Agropecuária Brasileira, 44, 1283-1290. http://dx.doi.org/10.1590/S0100-204X2009001000011

[14] Cruz, C.D. (2006) Princípios de genética quantitativa. Editora UFV, Viçosa.

[15] Cruz, C.D. (2013) Genes: A Software Package for Analysis in Experimental Statistics and Quantitative Genetics. Acta Scientiarum. Agronomy, 3, 271-276.

[16] Elsayed, A.Y., Silva, D.J.H., Mizubuti, E.S.G. and Carneiro, C.P. (2011) Combining the Monogenic and Polygenic Resistant Genes to Late Blight in Tomato. Journal of Plant Breeding and Crop Science, 10, 251-259.

[17] Faleiro, F.G., Cruz, C.D., Castro, C., Moreira, M.A. and Barros, E.G. (2002) Comparação de blocos casualizados e testemunhas intercalares na estimativa de parâmetros genéticos em feijoeiro. Pesquisa Agropecuária Brasileira, 37, 1675-1680. http://dx.doi.org/10.1590/S0100-204X2002001200001

[18] Rodrigues, G.B., Marim, B.G., Silva, D.J.H., Mattedi, A.P. and Almeida, V.D.S. (2010) Análise de trilha de componentes de produção primários e secundários em tomateiro do grupo Salada. Pesquisa Agropecuária Brasileira, 45, 155-162. http://dx.doi.org/10.1590/S0100-204X2010000200006

[19] Carvalho Filho, J.L.S., Gomes, L.A.A., Silva, R.R., Ferreira, S., Carvalho, R.R.C. and Maluf, W.R. (2010) Parâmetros populacionais e correlação entre características da resistência a nematóides de galhas em alface. Revista Brasileira de Ciências Agrárias, 6, 46-51. http://dx.doi.org/10.5039/agraria.v6i1a819

[20] Ferrão, M.A.G., Vieira, C., Cruz, C.D. and Cardoso, A.A. (2001) Causas genéticas das correlações entre caracteres do feijoeiro avaliados no inverno. Revista Ceres, 49, 573-582.

[21] Bernacchi, D., Beck-Bunn, T., Eshed, Y., Lopez, J., Petiard, V., Uhlig, J., Zamir, D. and Tanksley, S. (1998) Advanced Backcross QTL Analysis in Tomato. I. Identification of QTLs for Traits of Agronomic Importance from Lycopersicum 
hirsutum. Theoretical Applied Genetics, 97, 381-397. http://dx.doi.org/10.1007/s001220050908

[22] Galiana-Balaguer, L., Roselló, S. and Nuez, F. (2006) Characterization and Selection of Balanced Sources of Variability for Breeding Tomato (Lycopersicum) Internal Quality. Genetic Resources and Crop Evolution, 53, 907-923. http://dx.doi.org/10.1007/s10722-004-6696-6 
Scientific Research Publishing (SCIRP) is one of the largest Open Access journal publishers. It is currently publishing more than 200 open access, online, peer-reviewed journals covering a wide range of academic disciplines. SCIRP serves the worldwide academic communities and contributes to the progress and application of science with its publication.

Other selected journals from SCIRP are listed as below. Submit your manuscript to us via either submit@scirp.org or Online Submission Portal.
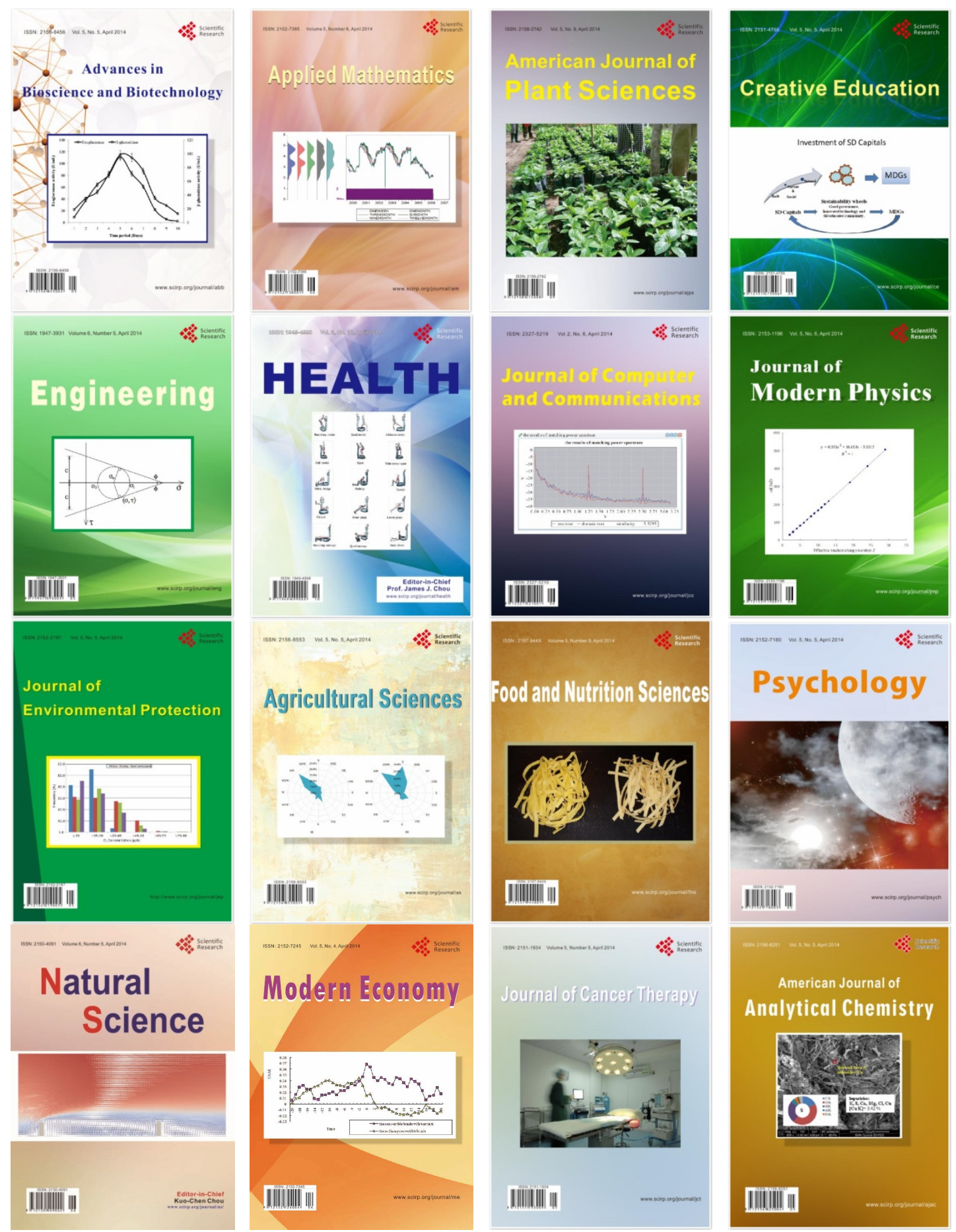